\title{
Crashing Out of a Career
}

Brenda Neufeld, MD

This article is meant as a personal reflection on my unexpected retirement, and includes memories and thoughts about my career with the Indian Health Service near the border with Mexico, serving the Tohono 0'odham tribe. (J Am Board Fam Med 2020;33:339-341.)

Keywords: Arizona, Family Physicians, Native Americans, Mexico, Personal Satisfaction, Retirement, United States Indian Health Service

My career began with a rainbow. I had driven cross country from Charleston, South Carolina to Sells, Arizona, stopping in Kansas where my mother joined me as a companion on the second half of my road trip. My hometown of Emporia seemed like a rough boundary or membrane between east and west, a place where tree-covered hills changed to grass-covered prairie. We enjoyed stopping in little towns along the way, places where cafes had signs saying, "free coffee for all law enforcement," bulletin boards held notices of community events, and all heads swiveled briefly when we walked in the door. Gradually, fields and plains became desert and mountains. The last stretch was a mountainflanked drive from Tucson through the Sonoran Desert, thick with saguaros, chollas and ocotillos. We could not believe that it was over 100 degrees in late September.

I made my job decision late in the third year of my family medicine residency, after considering and rejecting other options for reasons such as limited practice scope and minimal vacation time. Usually the opposite of a procrastinator, my tardiness in job choice did not worry me, as there would always be the option of continued shifts in small town South Carolina emergency departments. My interview on the Tohono O'odham reservation was

This article was externally peer reviewed.

Submitted 10 August 2019; revised 17 September 2019; accepted 24 September 2019.

From the Indian Health Service, San Xavier Health Center, Retired, Tucson, Arizona (BN); University of Arizona Clinical Assistant Professor, Tucson, Arizona (BN).

Funding: None.

Corresponding author: Brenda Neufeld, MD, 914 N. 4th Avenue, Tucson, AZ 85705 (E-mail: brendaneufeld@ hotmail.com). an afterthought, an add-on to what I thought was a more promising interview in Tucson. Although I had spent a month on the Zuni reservation during residency, like most people in our country I was ignorant of this tribe of desert-dwellers on their vast land bordering both Tucson and Sonora, Mexico. What was it that exerted a draw for me? Somehow the unpretentious facility, the petroglyphs near the small, dirt airstrip with the tattered windsock, the dedication of the medical staff, and the beauty of the desert conspired to seduce me. As I drove back to Tucson, a silver moon shone on the dark silhouettes of the desert plants and the mysterious mass of the mountains, and I knew that I would be working on the reservation.

But not forever, I thought-perhaps for two years. Charleston still exerted a pull, as did Kansas. This job would be an adventure, a way station on the way to something else that might be more permanent. As we drove over the rise into the small town of Sells, the rainbow seemed to be blessing my adventure, a gateway to new experience.

I soon discovered that not all would be rainbows; this was apparent when I discovered that my government housing had a gas leak. The Indian Health Service has always been and remains low on resources, and those who work with Native people learn how to make do with less. At times less meant a brutal shortage of medical staff, leaving those of us remaining exhausted as we provided clinic, inpatient, and emergency department care for a people dealing with a very high burden of diabetes and other chronic illness. Early on, clinic days were especially long. Call was frequent and often involved riding along with ambulance patients, as emergency medical technicians were few and 
paramedics nonexistent. A year in, I turned down federal loan repayment-I thought it unlikely that I could last for the two-year commitment. When I was diagnosed with lupus almost two years into my career with the O'odham, I felt that this added to the solidarity that I already felt with patients.

There were many rewards. I had what is so rare, long-term relationships with those I cared forbecause despite my initial plans and my health challenges, I stayed with the Indian Health Service on the Tohono O'odham reservation for 27 years, my entire career following residency. As a family doctor I had the perfect job. Early on I delivered babies who are now well into their 20s, and I treated numerous generations of many families. I learned about the rich culture of the Tohono O'odham as well as many other tribes. Tight family networks often reminded me of my ancestral background of rural midwestern Mennonites. It was revealing to see people in their homes on occasional home visits, and an honor to attend funerals at the beautiful San Xavier del Bac mission church. I met many fascinating people and heard many compelling stories. I always enjoyed seeing patients who had good senses of humor, despite their health issues; with some patients I laughed to the point of tears. I worked with dedicated medical and clinic staff, and together we made many hardwon improvements to patient care. I remain in a long-running book group with many of the doctors on staff, as well as their spouses.

Lupus continued to remind me of its presence, sometimes forcefully and sometimes softly. Eventually I had to stop taking call and gradually reduce my number of clinic hours. Since lupus means wolf in Latin, when it was active I had an image of a hungry wolf on the hunt. Late last year the wolf was particularly active, as she warned me insistently that work was no long compatible with caring for myself adequately. A flare of long-time pleuritic, pericardial, arthritic, and neurological symptoms that had waxed and waned through the years like unpredictable tides was now, along with migraines and crushing fatigue, too much to ignore. Of necessity my decision to retire was rather abrupt, with no chance to say good-bye during clinic visits as I would have liked. My symptoms were too severe to allow continued work on a temporary basis, and bureaucratic consideration of insurance waiting periods and federal disability retirement details also prevented me from doing any further hours in the clinic. Brexit was much in the news at the time and I joked sardonically that I needed to "crash out" of my career-retirement was a firm border between before and after.

Medicine is such a helping profession that at first I had a panicky feeling about not aiding people in any formalized fashion. Where would that caregiving impulse go now? The sudden absence of my patients felt like a hole in my life. In the immediate phase I was helped by trying to make the transition as orderly as possible, caring for patients by managing the handoff as best I could. I wrote a letter to be sent to all my patients, expressing regret that I needed to retire, thanks for my time with them, and assurance that my colleagues would take good care of them. I called as many long-time patients as I could. Patients were unfailingly kind and gracious as I bid them farewell. They were already aware that I had health challenges, as the signs were visible. I had worked while using an arrange of wraps, splints, special shoes, canes, walkers, and scooters, many of which came in handy as visual aids when I was urging devices on patients who had needed them. Not wanting visits to become about me, I had not talked much with patients about my health challenges. However, in response to questions I did often give short-hand versions that patients could often relate to. "I have neuropathy" illicited knowing sympathy, diabetes-related neuropathy being an ever-present scourge on the reservation. Perhaps the knowledge that we were both persons with impairments helped in some cases for the 2 of us to more easily form an alliance. As I called patients to say good-bye and to wish them well, I knew that patients would be curious and that vague explanations might make closure difficult for them. As a result I felt more free to talk about lupus and the challenges that it had brought me, while at the same time assuring patients that retirement would be good for my health and that they need not worry about me.

As I contemplated my new life, it was also helpful that I had started the process of acceptance years prior, during other major lupus flares. I had always known that early retirement could be a possibility, and now tried to cultivate gratitude that I had worked as many years as I did. Of course, I had not done the job perfectly, but I had the satisfaction of knowing I had done it to the best of my ability. My work would live on through the patient care that my colleagues picked up from me, the committee assignments and chair positions I handed over, and the policies I had written and revised that would 
remain in effect and gradually take different shapes under new hands. It was deeply fulfilling to think of the hundreds of medical students that I had supervised through the years, especially those who were influenced to choose family medicine for careers. I started work on this essay as soon as I knew I would need to retire, realizing somehow that it would be useful to review my career and put my thoughts into words.

I gradually came to feel that each of my myriad patient encounters continued to reside in me in some way, and that in some indefinable fashion the work of memory was continuing service, built into a career in medicine from the beginning. Some memories came back to me vividly whether from visits long ago or last year. Surely even a visit that I did not remember continued to be a part of me, just as a dinner with friends, a poetry reading, or a hike that I no longer was part of my layered experience. That experience of memory, both conscious and below the surface, consisted of so many strata of joy-prenatal patients awaiting new life, squirmy children happy to chatter as I examined them, college students anticipating their careers, elderly patients tenderly cared for by family, and so much more.

Of course there was also a toll of sadness. Historic trauma is a heavy load for large populations of peoples in our country, my patients included. Many patients have told me of unbearable personal trauma and crushing family tragedy. As physicians we all see the effects of social, environmental, and historic factors that we cannot change, and that was certainly the case for me. Many of my patients struggled with poverty, lack of opportunity, and the difficult burdens of chronic illness. Many died too young. Caring for this population was challenging, but incredibly meaningful.

Now I find meaning in time with family and friends, enjoyment of nature, and the study of humanistic pursuits other than medicine. Always a voracious reader, my appetite for books has only grown. I am taking full advantage of the University of Arizona Humanities Seminars, studying everything from Chinese poetry to the musiciology of the Beatles to the surrealist films of Luis Bunuel. In my more whimsical moments I imagine, without in any way regretting the path I did take, other paths I might have taken, such as my childhood ambition of becoming a librarian. Had that happened I might be now reviewing my library career, whimsically wondering what life would have been like had I become a family doctor! Life contains so much possibility for experience and knowledge that perhaps it takes a multiverse to contain it.

As I continue to live in Tucson, which abuts the reservation, I sometimes see patients and their families around town. I run into them in stores, at events, in church, and at the wonderful San Xavier Mission when I take visitors onto the reservation. I've attended a Tohono O'odham Community College basketball game, and I intend to go to patient funerals when I can. A friend asked me, "Are you still a doctor?" A question that surprised me. Retirement does not negate that identity, but it does change it. Now my interactions with former patients, though tinged by the memory of my time in examination rooms with them, are of human beings interacting on a more level playing field.

Does anyone really understand the term "life's work" at the start of a career? I am so grateful that I had the privilege of sharing joys and burdens with patients. I continue to do so in retirement through memory as I proceed with a different phase of life's work. As I told patients good-bye they offered their prayers, good wishes, and assurances that they would remember me. I am happy that my patients remain presences for me, even as I no longer see them in the same role, and that I can offer the same to them. Maybe I was successful in softening the experience of "crashing out." Maybe the border of retirement is more of a membrane than a wall.

To see this article online, please go to: http://jabfm.org/content/ 33/2/339.full. 